\title{
Memahami Peranan Perempuan Suku Minang Perantauan dalam Menjaga dan Meneruskan Komunikasi Budaya Matrilineal
}

\author{
Wira Yanti \\ (wirayanti_cute@yahoo.com)
}

(Alumni Jurusan Ilmu Komunikasi Universitas Semarang)

\begin{abstract}
Wira Yanti, G.311.10.0045. Understanding Minang Settler Women's Role in Preserving and Continuing the Communication of Matrilineal Culture (A study case to Minang women in Semarang). Final Project: Study Program S1 Communication Study Semarang University. The research is aimed at knowing the challenges and the roles of settler women (Minang ethnic) who stay in Semarang, as a minority group to preserve and continue the communication of matrilineal culture. The bases of the study are cultural communication, intra-cultural communication, symbolic interactionism and personal communication. One that is being questioned in the research is how to understand Minang women to preserve the communication of matrinilineal. The study used qualitative descriptive method by using the data from observation and reducing the data from indepth interview to be presented in a form of a research. Minang ethnic is a minority in Semarang however being settlers do not change the customs. Minang women in Semarang as main performers of matrilineal culture stay strong although they do not live in their hometown, they keep preserving and continuing the longestablished matrilineal culture. All of their action is done to protect the traditional values.
\end{abstract}

Kata Kunci : Peranan Perempuan, Komunikasi, Budaya

\section{PENDAHULUAN}

Budaya (adat) Minangkabau, sebagai budaya dominan di Sumatera Barat mempunyai pandangan tersendiri terhadap perempuan. Perempuan berada pada posisi yang terhormat sehingga seorang anak mengikuti garis keturunan ibu atau matrilineal dan perempuan berada pada pusat kekuasaan atau matriakhat.

Matrilineal merupakan salah satu aspek utama dalam mendefinisikan identitas masyarakat Minang. Adat dan budaya mereka menempatkan pihak perempuan bertindak sebagai pewaris harta pusaka dan kekerabatan. Garis keturunan dirujuk kepada ibu yang dikenal dengan Samande (se-ibu). Sedangkan ayah mereka disebut oleh masyarakat dengan nama Sumando (ipar) dan diperlakukan sebagai tamu dalam keluarga.

Kaum perempuan di Minangkabau memiliki kedudukan yang istimewa sehingga dijuluki dengan Bundo Kanduang, memainkan peranan dalam menentukan keberhasilan pelaksanaan keputusan-keputusan yang dibuat oleh kaum lelaki dalam posisi mereka sebagai mamak (paman atau saudara dari pihak ibu), dan penghulu (kepala suku). Pengaruh yang besar tersebut menjadikan perempuan Minang disimbolkan sebagai Limpapeh Rumah nan Gadang (pilar utama rumah).Walau kekuasaan sangat dipengaruhi oleh penguasaan terhadap aset ekonomi namun kaum lelaki dari keluarga pihak perempuan tersebut masih tetap memegang otoritas atau memiliki 
legitimasi kekuasaan pada komunitasnya.

Matrilineal tetap dipertahankan masyarakat Minangkabau sampai sekarang walau hanya diajarkan secara turun temurun dan tidak ada sanksi adat yang diberikan kepada yang tidak menjalankan sistem kekerabatan tersebut. Pada setiap individu Minang misalnya, memiliki kecenderungan untuk menyerahkan harta pusaka yang seharusnya dibagi kepada setiap anak menurut hukum faraidh dalam Islam hanya kepada anak perempuannya. Anak perempuan itu nanti menyerahkan pula kepada anak perempuannya pula dan begitu seterusnya. Sehingga sistem matrilineal akan semakin menguat dalam diri orang-orang Minangkabau walau mereka telah menetap di kotakota di luar Minang sekalipun dan mulai mengenal sistem Patrilineal.

Namun dibalik sekelumit budaya matrilineal yang telah mengakar dalam kehidupan orang minang perantauan khususnya maupun wanita minang yang tinggal di daerah aslinya secara umumnya terdapat sebuah sisi lain kehidupan budaya matrilineal yang telah terpengaruhi bahkan rapuh oleh budaya lain khususnya budaya barat. Pengaruh budaya barat itu merupakan salah satu tantangan bagi wanita minang perantauan yang notabene telah keluar dari area hukum adat istiadat minang dan secara langsung pondasi dalam mempertahankan budaya aslinya semakin lemah. Sedangkan tradisi ini dapat terus berlangsung dan terjaga ketika budaya tersebut mampu dijalankan oleh ibu dan anak wanitanya sebagai pelaku utama dalam budaya matrilineal. Peran anak wanita minang perantuan dalam menjaga interaksi yang harmonis serta komunikasi antar pribadi terhadap ibu ataupun pemangku adat minang di daerah aslinya, dapat menjaga dan mempertahankan budaya matrilineal dari pengaruh budaya barat di daerah perantauannya.

\section{Perumusan Masalah}

Masalah pokok yang akan dikaji dalam penelitian ini adalah:

1. Apa saja tantangan yang dihadapi oleh suku minang perantauan dalam menjaga dan mempertahankan komunikasi budaya matrilineal?

2. Bagaimana peranan perempuan dalam mempertahankan komunikasi budaya matrilineal pada suku minang terhadap pengaruh budaya barat?

\section{Tujuan Penelitian}

1. Memahami dan mendeskripsikan apa saja tantangan yang dihadapi oleh suku minang perantauan dalam menjaga dan mempertahankan komunikasi budaya matrilineal.

2. Memahami dan mendeskripsikan bagaimana peranan perempuan dalam menjaga dan mempertahankan komunikasi budaya matrilineal pada suku minang terhadap pengaruh budaya barat.

\section{TINJAUAN PUSTAKA \\ 2.1 Komunikasi Budaya}

Komunikasi dan budaya merupakan merupakan dua komponen yang tidak dapat dipisah dan keduanya saling terkait serta berhubungan dikarenakan keduanya adalah unsur yang mempengaruhi manusia dalam menyampaikan pesan dan informasi kepada informan ataupun sebaliknya. Seperti yang disampaikan oleh Mulyana dan Rakhmat bahwa "Budaya dan komunikasi tidak dapat dipisahkan oleh karena budaya tidak menentukan siapa bicara dengan siapa, tentang apa, dan bagaimana komunikasi berlangsusng, tetapi budaya juga turut menentukan bagaimana orang menyandikan pesan, makna yang ia miliki untuk pesan, dan 
kondisi-kondisinya untuk mengirim, memperhatikan dan menafsirkan pesan”. (Mulayana \& Rakhmat, 1990: 20).

Marhaeni Fajar menyampaikan, komunikasi adalah suatu kegiatan yang dilakukan secara sadar, disengaja serta sesuai dengan tujuan atau keinginan dari pelakunya (Marhaeni Fajar, 2009: 33). Kegiatan komunikasi pada prinsipnya adalah aktivitas pertukaran ide atau gagasan. Secara sederhana, kegiatan komunikasi dipahami sebagai kegiatan penyampaian dan penerimaan pesan atau ide dari satu pihak ke pihak lain, dengan tujuan untuk mencapai kesamaan pandangan atas ide yang dipertukarkan tersebut.

Apabila diurai satu per satu, didalam istilah komunikasi terdapat beberapa unsur yang menjadikan sebuah proses tercapainya kesepahaman maksud dan tujuan diadakannya komunikasi tersebut. Hal tersebut dapat dilihat pada apa yang diutarakan oleh Mulyana dan Rakhmat tentang definisi komunikasi sekarang didefinisikan sebagai suatu proses dinamik transaksional yang mempengaruhi perilaku dalam mana sumber dan penerimanya dengan sengaja menyandi (to code) perilaku mereka untuk menghasilkan pesan yang mereka salurkan lewat saluran (channel) guna merangsang atau memperoleh sikap atau perilaku tertentu. (Mulyana \& Rakhmat, 1990: 15)

Tiap pelaku komunikasi (manusia) mempunyai karakteristik yang berbeda yang dipengaruhi oleh latar belakang darimana orang itu berasal contohnya daerah minang, bahasa apa yang dipakai serta tingkat intelejensi yang dimiliki. Hal utama yang menjadi pokok proses komunikasi adalah bahasa, dikarenakan bahasa merupakan simbol yang kompleks karena terbentuk dari proses pengkombinasian dan pengorganisasian simbol-simbol, hingga memiliki arti khusus yang berbeda jika simbol itu berdiri sendiri. Bahasa menghubungkan simbol-simbol ke dalam proposisi, jadi merupakan refleksi dari realitas. Sehingga melalui bahasalah, manusia memahami realitas, berkomunikasi, berpikir dan merasakan. (Departemen Pendidikan dan Kebudayaan, 1977: 13)

Dari bahasalah biasanya masyarakat dapat diketahui bagaimana dan seperti apa kebudayaannya karena seperti yang disampaikan oleh Engkus Kuswarno bahwa bahasa menjadi inti dari komunikasi sekaligus pembuka realitas bagi manusia. Kemudian dengan berkomunikasi, manusia membentuk masyarakat dan kebudayaannya. Sehingga bahasa secara tidak langsung turut membentuk kebudayaan pada manusia. (Engkus Kuswarno, 2008: 8). Setiap masyarakat akan memiliki sistem komunikasi sendiri-sendiri, maka dengan sendirinya demi kelangsungan hidupnya, setiap masyarakat dapat membentuk kebudayaannya. (Engkus Kuswarno, 2008: 8).

Mulyana dan Rakhmat mengungkapkan, budaya adalah suatu konsep yang membangkitkan minat. Secara formal didefinisikan sebagai tatanan pengetahuan, pengalaman, kepercayaan, nilai, sikap makna, hirarki, agama, waktu, peranan, hubungan ruang, konsep alam semesta, objekobjek materi dan milik yang diperoleh sekelompok besar orang dari generasi ke generasi melalui usaha individu dan kelompok. (Mulyana \& Rakhmat, 1990: 20).

Inilah alasan mengapa komuikasi dan budaya satu kesatuan yang dapat diartikan bahwa budaya dijadikan landasan dalam berkomunikasi. Bila budaya beraneka ragam, maka beraneka 
ragam pula praktek-praktek komunikasi. (Mulyana \& Rakhmat, 1990: 20).

\subsection{Komunikasi Antar Budaya}

Masalah utama dalam komunikasi antarbudaya adalah kesalahan dalam persepsi sosial yang disebabkan oleh perbedaan-perbedaan budaya yang mempengaruhi proses persepsi. (Mulyana \& Rahmat, 2001: 34). Dalam proses komunikasi antar budaya terjadi sebuah hambatan dan masalah yang sama seperti yang dihadapi oleh bentukbentuk komunikasi yang lain contohnya ketika warga suku minang berinteraksi dengan warga suku yang berbeda sesuai dimana mereka bermukim saat merantau. Dalam menciptakan sebuah keefektifan komunikasi antarbudaya, komunikasi akan lengkap bila penerima pesan yang dimaksud mempersepsi atau menyerap perilaku yang disandi, memberi makna kepadanya dan terpengaruh olehnya. Dalam transaksi komunikasi harus dimaksukkann semua stimuli sadar-tak sadar, sengaja-tak sengaja, verbal, non verbal yang kontekstual yang berperan sebagai isyarat-isyarat kepada sumber dan penerima tentang kualitas dan kredibilitas pesan. Dalam proses interaksi antarbudaya sama halnya dengan harus memperhatikan delapan unsur komunikasi, kedelapan unsur tersebut yaitu, sumber (source), penyandian (ecoding), pesan (message), saluran (channel), penerima (receiver), penyandian balik (decoding), respon penerima (receiver response) dan yang terakhir umpan balik (feedback).

Adapun pemahaman komunikasi antar budaya dapat menjadi acuan ketika terjadi pembauran antar budaya contohnya ketika warga minang tetap mampu mempertahankan identitas serta budaya minangnya di kala mereka merantau dan bermukim bersama pada lingkungan yang terdapat suku lain ataupun terkena imbas budaya barat.

\subsection{Interaksionisme Simbolik}

Suatu komunikasi dapat dikatakan efektif apabila pesan dapat diterima dan tercapainya tujuan oleh pelaku komunikasi. Seorang anak wanita minang perantauan haruslah memiliki interaksi serta terjalinnya komunikasi yang baik kepada ibunya yang ada di tanah kelahiran aslinya. Hal tersebut sebagai langkah untuk tetap menjaga komunikasi untuk memperoleh pengetahuan lebih budaya matrilineal. Seperti yang Blumer sampaikan, Ini merupakan proses sosial dalam kehidupan kelompok yang menciptakan dan menjunjung tinggi aturan-aturan bukan sebaliknya. (Blumer, 19).

Proses sosial tersebut dapat dicapai dengan tiga bagian yang paling mendasar yakni gerak tubuh awal dari setiap individu, respon dari orang lain terhadap gerak tubuh tersebut, dan sebuh hasil. (Little Jhon, 2009: 232). Hasil yang didapat adalah sebuah makna ataupun arti tindakan yang dilakukan oleh pelaku komunikasi tersebut dalam hal ini adalah pelaku komunikasi budaya matrilineal antara ibu dan anak wanita minang perantauan.

Fenomena tersebut diperkuat oleh penuturan Donad Ellis yang menuturkan bahwa topik-topik utama dari sosiologi (misalnya etnis) tidak pernah benarbenar dilihat, tetapi ada di dalam dan hidup melalui kegiatan-kegiatan individu dalam situasi-situasi kecil. (Donald Ellis, 1999: xii).

\subsection{Komunikasi Antar Pribadi}

Komunikasi antar pelaku budaya matrilineal yakni ibu dan anak wanita minang perantauan diperkuat lagi dengan adanya komunikasi antar pribadi. Komunikasi yang dilakukan antara dua orang ini diperuntukkan 
untuk menjalin komunikasi yang intim antar dua orang tersebut untuk saling berdialog demi mendapatkan informasi mendalam atas tujuan tertentu. Joseph A. Devito dalam bukunya "The Interpersonal Communication Book" mendefinisikan komunikasi antarpribadi sebagai: "Proses pengiriman dan penerimaan pesan-pesan antara dua orang atau di antara sekelompok kecil orang-orang, dengan beberapa efek dan beberapa umpan balik seketika". Berdasarkan definisi itu, komunikasi antarpribadi dapat berlangsung antara dua orang yang memang sedang berduadua atau antara dua orang dalam suatau pertemuan. Pentingnya situasi komunikasi antarpribadi ialah karena prosesnya memungkinkan berlangsung secara dialogis, di mana selalu lebih baik daripada secara monologis. Monolog menunjukkan suatu bentuk komunikasi di mana seorang berbicara, yang lain mendengarkan, jadi tidak terdapat interaksi.

Dengan membicarakan tentang diri kita sendiri pada orang lain, kita akan mendapatkan perspektif baru tentang diri kita sendiri dan memahami lebih mendalam tentang sikap dan perilaku kita (Marhaeni Fajar, 2009: 78). Sebagai suatu proses, komunikasi antarpribadi merupakan rangkaian tindakan, kejadian dan kegiatan yang terjadi secara terus menerus atau bisa dibilang merupakan suatu yang dinamis (Marhaeni Fajar, 2009: 81). Bila diartikan lebih luas, dalam komunikasi antar pribadi, seorang komunikator bisa sekaligus menjadi komunikan yang dalam prosesnya lagi berlangsung secara terus menerus dan tidak tahu kapan akan berakhir. Tahapan-tahapan dalam komunikasi antarpribadi adalah (1) Kontak (first impression), (2) Perkenalan, (3) Pertemanan, (4) Decline (puncak), (5) Perpecahan (Marhaeni Fajar, 2009: 86). Komunikasi antarpribadi sebagai suatu bentuk perilaku, dapat berubah dan sangat tidak efektif. Pada suatu saat komunikasi bisa lebih buruk dan pada saat lain bisa lebih baik (Marhaeni Fajar, 2009: 84). Tetapi dibalik itu semua terdapat suatu keunikan dalam proses komunikasinya yang dilakukan secara fleksibel.

\section{METODOLOGI PENELITIAN}

Penelitian ini mengambil jenis penelitian deskriptif kualitatif. Dengan penelitian ini, di harapkan mampu memberikan informasi deskriptif kualitatif dengan lebih terjabar. Penulis menggunakan data primer dan data sekunder. Data primer merupakan sumber data penelitian yang diperoleh secara langsung dari sumber asli yang berupa kata-kata serta tindakan (Lofland dalam Lexy J. Moleong, 2005: 157). Sumber data primer yang Penulis gunakan adalah warga suku Minang dari Sumatera Barat yang berdomisili di kota Semarang sebagai hasil wawancara dan observasi.

Sementara itu, data sekunder merupakan data tambahan yang diperoleh dari catatan-catatan dokumen dan juga sumber kepustakaan (Lofland dalam Lexy J. Moleong, 2005: 157). Data sekunder Penulis peroleh dari berbagai media, seperti buku-buku, $e$ book mengenai hal yang bersangkutan, serta membaca beberapa arsip-arsip untuk menambah wawasan Penulis mengenai penelitian ini.

Penelitian ini menggunakan cuplikan yang bersifat selektif, dengan menggunakan pertimbangan berdasarkan konsep teoritis yang digunakan, keinginan pribadi dari Penulis, dan lain sebagainya. Oleh sebab itu, penelitian ini bersifat purposive sampling. Penelitian yang bersifat purposive sampling memiliki cara meneliti dengan selektif, juga berdasarkan pada konsep teoritis yang 
digunakan, keinginan pribadi dari Penulis, dan lainnya. Tujuan dari penelitian sejenis ini adalah untuk mendalami data sehubungan dengan tidak adanya realitas tunggal (Goetz dan LeCompte dalam Gunawan, 2002: 36).

\section{HASIL DAN PEMBAHASAN}

Pada bab ini Peneliti akan memaparkan hasil penelitian yang Peneliti lakukan, yakni observasi dan wawancara mendalam terkait dengan perumusan masalah yang dituliskan di bab 1. Penulis memilih Perempuan Minang sebagai narasumber utama, karena menurut hasil penelitian Penulis, Perempuan Minang merupakan ahli waris yang mempertahankan garis keibuan (matrilineal).

Penelitian yang dilakukan oleh Peneliti di Kota Semarang mengenai budaya masyarakat Minang sebagai suku minoritas, menyorot ke beberapa hal sebagai poin pembahasan. Yaitu mengenai tantangan yang dihadapi oleh suku minang perantauan dalam menjaga dan mempertahankan komunikasi budaya matrilineal dan peranan perempuan dalam mempertahankan komunikasi budaya matrilineal pada suku minang terhadap pengaruh budaya barat, orang Minang terus mempertahankan kebudayaannya dan mencoba mejalankannya walaupun sebagai suku minoritas disemarang. Dari penelitian ini, diketahui bahwa suku Minang yang berdomisili di Kota Semarang ini tetap menjalankan dan melaksanakan berbagai adatnya, walaupun sebagai suku yang minoritas. Hanya saja, adat-adat yang mereka lakukan tidak secara terang-terangan seperti yang biasa mereka lakukan di kampung halamannya.

Selain itu Bahasa Minang jarang digunakan dalam percakapan sehari-hari dan disini sulit bertemu dengan sesama orang minang, bertemu papabila ada acara-acara tertentu, jadi kalau bertemu orang sesama minang baru menggunakan bahasa minang.

Terkait dengan Interaksionisme Simbolik yang Penulis cantumkan sebelumnya, dimana dalam berkomunikasi sering terjadi komunikasi simbolik. Teori interaksionosme simbolik adalah hubungan antara simbolik dengan interaksi. Menurut mead, orang bertindak berdasarkan makna simbolik yang muncul dalam situasi tertentu. Sedangkan simbol adalah representasi dari sebuah fenomena, dimana simbol sebelumnya sudah disepakati bersama dalam suatu kelompok dan digunakan untuk mencapai sebuah kesamaan. Dari teori interaksi simbolik ini penulis mendapat adanya komunikasi simbolik yang terdapat dalam komunikasi antar ibu dan anak perempuan.

Makna adalah "produk sosial" atau "ciptaan yang dibentuk dalam dan melalui pendefinisian aktifitas manusia ketika mereka berinteraksi".(Blumer, 1969, hal. 5).

Makna dimodifikasi melalui proses interpretif. Blumer menyatakan bahwa proses interpretif ini memiliki dua langkah. Pertama, para pelaku menentukan benda-benda yang mempunyai makna. Blumer berargumen bahwa bagian dari proses ini berbeda dari pendekatan psikologis dan terdiri atas orang yang terlibat didalam komunikasi dengan dirinya sendiri. Langkah kedua melibatkan si pelaku untuk memilih, mengecek, dan melakukan transformasi makna didalam konteks dimana mereka berada.

Harta pusaka tinggi yang diturunkan ibu ke anak perempuannya bisa berupa benda-benda seperti sawah, ladang, tanah, rumah, dsb. Benda-benda tersebut berupa amanah dari keluarga yang memiliki makna dan arti dimana warisan tersebut harus dijaga dan 
dipelihara oleh anak perempuan demi menjaga ketahanan keluarga. Apabila warisan tersebut tidak dipelihara dan dijaga maka suatu suku atau kaum akan kehilangan hartanya sehingga tidak adalagi jaminan hidup bagi saudara dan kemenakan perempuan (saudara perempuan) dimasa-masa yang akan datang, dan akan terjadi penurunan nilai-nilai kekeraban matrilineal itu sendiri.

Cara menjaga kebudayaan oleh orang Minang, melalui beberapa cara seperti misalnya pendidikan dan sosialisasi. Meningkatkan kembali sistem pendidikan di keluarga. Keluarga harus menjadi suatu sistem pendidikan dini bagi anak yang akan menjelang dewasa, disamping wadah untuk menjelaskan hubungan kekerabatan sesuai adat yang berlaku, perlu sosialisasi adat dan hubungan kekerabatan ini lewat pendidikan formal ataupun nonformal, Perlu kembali pengajaran adat melalui suku, Dimulai dari dalam keluarga mengajarkan adat istiadat dan hubungan kekerabatan dan juga penggunaan bahasa ibu (bahasa minang), dalam sosialisasi pendidikan adat istiadat, diberikan dalam berbagai bentuk kesenian, diskusi keluarga, sehingga nilai-nilai budaya Minang tersebut dapat tersampaikan dan juga perlu ada sosialisai pemahaman tentang budaya Minangkabau yang menggugah masyarakat Minang agar peduli dengan adat dan budaya Minangkabau, Menggali dan memahami nilai-nilai luhur adat budaya Minangkabau.

Pendidikan dan Sosialisasi mengenai konsep-konsep budaya Minangkabau ini tentu saja sangat memotivasi dan membantu masyarakat dalam membentuk kepribadiannya dan menentukan sikap ke depan dalam rangka mempertahankan budaya Minangkabau dari pengaruh budaya barat yang begitu kuat masuk dan mempengaruhi perilaku masyarakat sehingga cenderung tidak lagi berpijak ke budaya Minangkabau bahkan akan bisa menyebabkan hilangnya identitas diri.

Bagi kaum perempuan, dengan memahami peran dan kedudukannya dalam adat Minangkabau itu secara mendalam tentu saja lebih memotivasi dirinya dan memberikan inspirasi untuk menjalankan peranannya sebagai perempuan Minang. Dengan harapan, ketika seorang perempuan Minang meningkatkan kompetensi dirinya ia tetap berpijak pada konsep adat Minangkabau yang menjadikan ia nantinya mampu berperan sebagai "Bundo Kanduang" yang diinginkan dalam Kato Pusako tersebut.

Kedudukan dan peranan perempuan di Minangkabau di Sumatera Barat dapat dilihat dari dua segi. Pertama, masyarakat itu mampu bertahan dan mempertahankan nilainilai kebudayaannya. Kedua, perempuan sebagai pemegang amanah dalam melindungi dan mewujudkan kesejahteraan masyarakat. Keduaduanya saling berkaitan dan ada kaitan bukan saja dengan kebijaksanaan perempuan sendiri, tetapi juga kebijakan orang tua dalam membimbing anaknya. Lanjutan daripada itu, adalah disarankan apabila hendak mengadakan perubahan, mudharat dan manfaatnya hendaklah dipertimbangkan. Pertimbangan itu adalah untuk menjaga nilai budaya dan adat yang telah dipunyai masyarakat Minangkabau.

\section{KESIMPULAN}

Matrilineal adalah Budaya dari tanah Minang yang masih terjaga sampai saat ini, ditengah masuknya budaya barat, budaya Matrilineal yang mengagungkan kaum Wanita ini masih dijaga kelesatriannya oleh keturunan keturunan Minang. 
Berdasarkan pengamatan Peneliti selama melakukan observasi, berikut dengan wawancara mendalam terhadap beberapa narasumber, Peneliti menyimpulkan cara untuk mempertahankan komunikasi budaya matrilineal, adat, kebiasaan yang diwariskan secara turun temurun, dimulai melalui keluarga terlebih dahulu, agar adat budaya dapat tertanam sejak dini dan bahwa Budaya Matrilineal masih sangat terjaga kelestariannya, serta para keturunan suku minang menerima dengan baik budaya ini dan menganggapnya sebagai budaya yang positif dan banyak memberikan manfaat. Para perempuan minang perantauan tetap menjalankan perannya sebagaimana semestinya dan mereka memandang Budaya Matrilineal adalah budaya yang positif walaupun berada diperantauan dan jauh dari keluarga tetapi mereka tetap menerapkan budaya ini dimanapun mereka berada.

Ditengah masa moderenisasi ini budaya dari tanah kelahiran sering kali dilupakan oleh generasi - generasi masa kini, terutama remaja - remaja. Sering kali budaya asli mereka yang seharusnya dilestarikan malah dianggap kuno dan tidak modern sehingga mereka tidak mau bahkan untuk sekedar mengenalnya. Diantara banyaknya Budaya Indonesia yang hampir mati, masih ada satu budaya dari Tanah Minang Kabau yang masih mengakar dan tertanam dijiwa setiap masyarakatnya, termaksud perempuan minang.

Sebagai perempuan minang yang hidup di perantauan dan ditengah masuknya budaya barat atau moderenisasi kedua subjek menunjukan sikap yang sangat pro terhadap budaya tanah kelahiran mereka, bahkan mereka berencana untuk tetap menanamkan pesan luhur budaya tersebut kepada keturunan mereka nantinya. Mereka juga mengajak generasi muda lainnya untuk selalu melestarikan Budaya kita yang sangat beragam ini dan berpendapat bahwa seharusnya kaum muda bisa memandang budaya tersebut dari sisi yang positif.

\section{DAFTAR PUSTAKA}

[1] Alo Liliweri, 2007. Dasar - Dasar Komunikasi Antar Budaya, Yogyakarta, Pustaka Pelajar.

[2] Engkus Kuswarno. 2008. Etnografi Komunikasi. Bandung : Widya Padjadjaran.

[3] Gunawan Witjaksana. 2005. Pokokpokok Penelitian dalam Metodologi Penelitian Komunikasi Kualitatif. Buku ajaran Ilmu Komunikasi USM.

[4] Lexy. J. Moleong. 2005. Metodologi Penelitian Kualitatif. Bandung : PT. Remaja Rosdakarya.

[5] Littlejhon, S \& A. Foss, Karen, 2009. Theories of communication (9). Jakarta : Salemba Humanika.

[6] Marhaeni Fajar. 2009. Ilmu Komunikasi :Teori dan Praktik. Yogyakarta : Graha Ilmu.

[7] Mulyana, Deddy \& Rahmat, Jalaluddin. 1990. Komunikasi Antar Budaya. Bandung : PT. Remaja Rosdakarya. 